\title{
1-Phosphatidylinositol 4,5-Bisphosphate Phosphodiesterase Gamma-1
}

National Cancer Institute

\section{Source}

National Cancer Institute. 1-Phosphatidylinositol 4,5-Bisphosphate Phosphodiesterase

Gamma-1. NCI Thesaurus. Code C104824.

1-phosphatidylinositol 4,5-bisphosphate phosphodiesterase gamma-1 (1290 aa, 149 $\mathrm{kDa}$ ) is encoded by the human PLCG1 gene. This protein is involved in the intracellular propagation of signals from ligand-dependent receptor-type tyrosine kinases. 